NBER WORKING PAPER SERIES

\title{
MODELING THE OFFSHORING \\ OF WHITE-COLLAR SERVICES: \\ FROM COMPARATIVE ADVANTAGE \\ TO THE NEW THEORIES OF TRADE AND FDI
}

\author{
James Markusen \\ Working Paper 11827 \\ http://www.nber.org/papers/w11827
NATIONAL BUREAU OF ECONOMIC RESEARCH
1050 Massachusetts Avenue
Cambridge, MA 02138 \\ December 2005
}

Prepared for the Brookings Forum, "Offshoring White-Collar Work: The Issues and Implications", May 1213, 2005. The views expressed herein are those of the author(s) and do not necessarily reflect the views of the National Bureau of Economic Research.

(C2005 by James Markusen. All rights reserved. Short sections of text, not to exceed two paragraphs, may be quoted without explicit permission provided that full credit, including $(\mathcal{C}$ notice, is given to the source. 
Modeling the Offshoring of White-Collar Services: From Comparative Advantage to the New Theories of Trade and FDI

James Markusen

NBER Working Paper No. 11827

December 2005

JEL No. F2

\begin{abstract}
$\underline{\text { ABSTRACT }}$
Trade theory consists of a portfolio of models. What elements might be useful in modeling the offshoring of white-collar services, or do these issues call for an entirely fresh approach? I try to identifying some of the important aspects of this phenomenon and then argue that modeling could focus on (a) vertical fragmentation of production, (b) expansion of trade at the extensive margin, (c) fragments that differ in factor intensities and countries that differ in endowments, and (d) knowledge or capital stocks of countries or firms that are complementary to skilled labor, and create missing inputs for countries otherwise well suited to skill-intensive fragments. I argue that we can make good progress by selecting a number of "modules" from existing theory. I use these to formulate a series of simple "template" models which capture many of the characteristics of offshoring, and then use those models to identify the effects of technological or institutional changes which allow offshoring of white-collar services to occur.

James Markusen

Department of Economics

University of Colorado

Boulder, CO 80309-0256

and NBER

james.markusen@colorado.edu
\end{abstract}




\section{1. $\quad$ Introduction}

I have always viewed trade theory as consisting of a portfolio of models. ${ }^{1}$ There are many underlying causes of or motives for trade, and it is probably productive to have a series of models analyzing just a few of these at a time rather than attempt one grand model which includes all possible bases for trade. At the other extreme, we could envision a model for every industry and every country pair and perhaps every multinational firm. At this point, theory coincides with case-study analysis and we learn nothing of any generality. So a parsimonious set of models, the number of elements greater than one but less than say one thousand, is probably a good scientific objective.

My first question in approaching my assignment for the Brookings Forum is whether or not we can make good progress from off-the-shelf elements of our portfolio of models, or do we need an entirely new approach? The methodology I follow in order to answer this question is to first ask another question: what are the important characteristics of the offshoring of white-collar services that we wish to capture in a theory model? Having identified a number of these characteristics, I am led toward the conclusion that we can indeed go a long way by drawing from our portfolio of models, mixing and matching elements to create a useful, empirically relevant, and productive sub-theory for offshoring white-collar services.

I sketch the outlines of a number of candidate "template" models, each of which captures some aspect of the problem. From analytical insights and numerical simulations of these models, I am then able answer questions about the effects and consequences of technological or

\footnotetext{
${ }^{1}$ I got this idea from Tjalling Koopmans’ (1957) “Three Essays on the State of Economic Science", which is still of great value today. Koopmans used the term "sequence of models".
} 
institutional innovations which permit offshoring to arise. These include effects on the national income of each country, effects on the relative and real prices of skilled and unskilled labor in each country, and effects on the volume of trade in goods (e.g., are trade in goods and services complements or substitutes).

Before proceeding, I wish to emphasize that my goal here is to suggest ways of thinking about the issues in formal models. I was distressed following my presentation at the Brookings conference to find many people focusing on the results of some simulations, particularly with respect to "northern" welfare (read as US welfare). All readers should understand that no theory says that a move from partial liberalization to full liberalization makes everyone better off. To push the point further, I am confident that I can concoct a model to generate any result desire by a reader with a deep pocketbook. I have tried hard to stick to reasonable and relevant structures and assumptions, but even so, qualitative results sometimes depend on specific parameter values as we shall see.

In the following section, I provide a brief overview of some of our theory portfolio, and then identify some of the crucial aspects of offshoring we wish to capture in section 3. Section 4 begins a series of template models. 


\section{2. $\quad$ Our Theory Portfolio}

I will argue that we can usefully draw from a numbers of existing theories and models of trade in order to make progress on offshoring. I don't claim that the list is exhaustive or than alternative taxonomies might not be more useful, I just believe that these particular elements will prove useful.

(A) Comparative advantages theories of trade in goods. Our traditional trade theory tends to focus on differences among countries as the primary motive for trade. The Ricardian model of trade, in which countries differ in technologies, is usually listed first. Second, the work-horse model of trade is factor-proportions or Heckscher-Ohlin theory, in which differences in factor intensities among goods intersect with differences in factor endowments among countries to determine a pattern of comparative advantage and trade. This ever-popular approach not only gives an intuitive explanation for the direction of trade, but permits a details analysis of the distributional consequences of trade within countries in addition to aggregate gains from trade. Other country characteristics which fit here include differences in market distortions among countries and country (internal market) size.

(B) Non-comparative-advantage theories of trade. This category is largely the domain of the so-called "new trade theory", a term I dislike: industrial-organization approach to trade is more apt (and avoids the awkward problem of what to call the theory that comes after the new theory). The principal motives for trade are scale economies, imperfect competition, and product differentiation.

A sub-category of this branch of theory involves the existence of firm-specific assets, an especially useful approach to the theory of the multinational firm. These range from managerial 
and technology assets to brand names and trade marks. This approach has resurfaced more recently in heterogeneous firm models, in which (potential) firms get productivity "draws" from some distribution that make some firms more productive than others (Melitz 2003; Helpman, Melitz and Yeaple, 2004).. Productivity in turn determines whether firms enter foreign markets and if so by exports or foreign production.

(C) Trade in Factors. While trade in goods has drawn the most attention in both theory and empirical analysis, the topic of trade in factors has always lurked in the background. Generalization of theoretical findings are difficult, but the overall impression is that trade in goods and factors tend to be substitutes in comparative-advantage models. Indeed, Mundell's (1957) early demonstration of this might explain the lack of interest in trade in factors. An elegant treatment of this substitutability is found in Jones et. al. (1986). Later, it was shown that trade in goods and factors tend to be complements for virtually any other causes of trade other than factor proportions (Markusen, 1983) and even in some versions of factor-proportions models (Neary, 1987).

(D) Theories of foreign direct investment and arm's length trade in firm-specific assets. I think it is fair to say that, until the mid-1980s, FDI was just viewed as part of the theory of capital movements in a factor-proportions world. Eventually, a huge amount of empirical evidence, most notably that most FDI is among high-income capital-rich countries, led to new approaches to what we are now calling offshoring.

Theory bifurcated into two branches. One could be called the vertical or resourceseeking approach, an early example of which is Helpman (1984). This is in fact a natural extension of factor-proportions comparative-advantage models in which activities differ in factor 
intensities and countries differ in factor proportions. The alternative is the horizontal or marketseeking approach, in which firms exploit firm-specific assets in multiple markets, an early example of which is Markusen (1984). The latter is more a part of non-comparative-advantage theory and, while both approaches are important, does the job of explaining the large volume of intra-industry FDI among the high-income countries. I believe that it is accurate to say that the overwhelming weight of empirical evidence, beginning with Brainard (1993), is more consistent with the horizontal approach.

Intertwined with this literature on FDI is a long-standing literature on "internalization", now being called by its inverse name, "outsourcing”. Both terms are addressing the issue of whether or not firms keep certain activities internal to the firm or use arm's length contractors to supply intermediates, assembly, services, distribution and so forth. Early analyses include Dunning (1977). Some more recent authors seem unaware of this large literature, but it is still a pertinent antecedent and changing the name from internalization to outsourcing doesn't change that fact. This literature argues that the choice between internal and arm's-length modes depend on issues such as moral hazzard, adverse selection, hold up, contract enforcement and intellectual property protection.

(E) Trade in business services (non-factor, non-trade-mediating services). There was an earlier wave of interest in trade in business services in the late 1980s, in Canada in particular. In my view, and I was a participant, the theory that came out of this was not very successful. Several authors got bogged down in trying to define services, an elusive goal as Trefler has so nicely indicated with his quote from Justice Stewart. One traditional view about business services is that they are hard to trade, requiring the spatial and temporal proximity of supplier 
and customer. Herb Grubel (1987) in Canada went so far as to argue that all trade in services is embodied in goods or persons. It is very clear from the topics we are considering today that this view is at best badly outdated.

One area where progress has been made is in the theory of the multinational. The modern view is that parent firms are exporters of the services of knowledge-based assets to foreign subsidiaries (although goods and intermediates are often traded as well) (Markusen, 1995, 2002).

(F) Liberalization: trade expansion at extensive margin. Much traditional trade theory involves liberalization expanding the volume of trade in existing traded goods. We could call this expansion at the intensive margin. But these models don't seem very appropriate to the current discussion in which we are looking at new things being traded. Some existing theory bears on this. In comparative-advantage models, liberalization expands trade at the intensive margin, but some "middle” goods can become traded as trade costs fall, as in the DornbuschFischer-Samuelson (1977) Ricardian continuum model. Yi (2004) has a neat Ricardian model in which goods are produced in distinct stages of production that can be geographically fragmented. Other valuable empirical evidence is found in Hummels, Ishii and Yi (2001).

In the theory of the horizontal multinational, investment liberalization allows intra-firm trade in the services of knowledge-based assets, so more things are traded. For vertical multinationals and arm’s length offshoring, innovations in technology, liberalization, or institutions (IPP) allows fragmentation of the production chain so that more things are traded: capital-intensive intermediates go out, labor-intensive assembly takes place abroad in laborabundant countries, with much of the final output shipped back to the parent's county. In all of 
these models, trade expands at the extensive margin.

\section{Empirical Characteristics of Offshoring of White Collar Services to Capture in Theory Models}

Here is a wish list of characteristics we might wish have in theoretical models of offshoring of white-collar services.

(A) Expansion of trade at the extensive margin: new things traded due to innovations in communications and technology.

This poses a number of challenges to theory, especially the fact that we are talking about non-marginal changes and discrete movements of something being non-traded to potentially lots of trade. Traditional comparative-statics analysis is of little use: they focus on marginal changes in activities which are already in use in the benchmark.

(B) Vertical fragmentation of production: the new traded services tend to be intermediates, may be upstream, downstream, or not part of a sequence.

Traded white-collar services often have a number of important characteristics that cannot be captured in the simplest off-the-shelf models which assume a set of final goods. One is that they may be firm-specific rather than bought and sold on arm's-length markets. Another is that they may form part of a particular production sequence, such as being a well-defined upstream (design) or downstream (after sales service) component of overall production. A third is that there may be crucial complementarities among different elements of the production chain, such as between skilled labor and telecommunications equipment and infrastructure.

(C) Offshoring of medium-skilled or even highly-skilled services to skilled-laborscarce countries. At odds with factor-proportions theories?

The simplest off-the-shelf 2x2 Heckscher-Ohlin model is not going to offer insights as to why relatively skilled-labor-intensive services are being offshored to very skilled-labor-scarce 
countries. One of the most important tasks of theory, in my opinion, is to develop richer, but empirically-plausible models as to why this phenomenon is taking place. Yet it is not necessarily the case that the factor-proportions approach to trade has to be abandon, just that it must be enriched to include multiple goods and/or factors, so that fragmentation and the complementarities just discussed can be analyzed.

(D) Reversal in the direction of trade from existing multinationals models. New offshoring is exports of services back to high-income-country firms (intra-firm back to parents or via arm's-length contracting).

Trade in white-collar services is not new. The modern theory of the multinational has emphasized that parents are exporters of white-collar services, including management and engineering consulting, marketing, finance and so forth to their subsidiaries. One thing that is relatively new and which has generated much of the current interest is the reversal in the direction of trade that we are seeing. In some ways this is closely related to the previous point.

(E) Firms or specifically owners of knowledge-based assets, may offshore skilledlabor intensive activities that are complements to these assets

A plausible worry is that skilled workers in the high-income countries are being hurt, while their companies are profiting from offshoring. This cannot be dismissed and requires investigation. To me, it calls for at least a three-factor model, in which firms possess specific factors or other assets which are complements to skilled labor. An example mentioned above is software engineers as complements to telecommunications equipment and network infrastructure, in which the third factor is physical capital. Or it could be that software engineers are complementary with managerial sophistication, organization infrastructure, and marketing channels. The complementary input is knowledge-based assets.

Without services trade, you can train an engineer in India, but there is no demand for his 
or her skills: there is nothing useful to do. The implication is that, in the absence of offshoring, these skilled workers are cheap even though they are relatively scarce in comparison with the country with the complementary factors. Offshoring allowing trade in the third factor causes that factor (or its services) to move to the skilled-labor-scarce country to combine with cheap skilled labor there. This set up obviously has the elements of a story in which skilled labor is harmed in the high-income country, while owners of the complementary physical or knowledgebased assets benefit.

This phenomenon is relatively easily modeled in either a competitive, multi-factor model, or using Markusen's knowledge-capital approach to the multinational. The latter approach has also proved a useful starting point for looking at the internalization versus outsourcing decision in relation to the offshoring decision. The idea is that transacting in knowledge-based assets creates special problems for the owner (multinational firm). For example, there are several labor-turnover models in which workers in the host country absorb or learn the substance of the knowledge-based assets and can defect to start rival firms. Other issues that have been considered in the theory literature involve asymmetric information, reputations, and hold-up.

The next few sections of the paper construct and analyze some simple template models that incorporate these features. All of the models presented in the paper have been coded into numerical simulation models using GAMS. Code for these models is available from the author. An appendix to the paper lays out the structure of Model 1. 


\section{4. $\quad$ Model 1: a 3x2x2 Heckscher-Ohlin Model with Fragmentation}

Suppose we begin with a simple two-final-good, two-factor, two-county Hecksher-Ohlin model and then allow one good to fragment into two separate production activities, giving three in total. If we assume free trade, just considering free versus prohibitive fragmentation costs, we do not need to specify which is the upstream and which is the downstream activity. For a much more comprehensive treatment of this case, see Markusen and Venables (2005). Here are the principal features of the model.

(A) Two factors of production: skilled (H) and unskilled (U) labor

(B) Two final goods, three production activities

$$
\begin{array}{llll} 
& \text { Y } & \text { unskilled-labor intensive } \\
\mathrm{X} & - & \text { skilled-labor intensive } \\
\mathrm{X} & - & \text { can fragment into high-tech manufacturing }(\mathrm{M}) \text { and services (S) } \\
& \mathrm{M} & - & \text { more skilled-labor intensive than } \mathrm{X} \\
& \mathrm{S} & - & \text { middle skill intensity: less than } \mathrm{X} \text {, more than } \mathrm{Y}
\end{array}
$$

(C) Two competitive, constant returns economies

$$
\begin{array}{ll}
\text { North - } & \text { high-skilled abundant } \\
\text { South - } \quad \text { low-skilled abundant }
\end{array}
$$

The service component of good $\mathrm{X}$ is thus chosen to have a middle factor intensity between integrated $\mathrm{X}$ and good $\mathrm{Y}$; specifically, the complete ranking from most to least skill intensity is: $M>X>S>Y$. This choice definitely matters for the results. We are thinking here of things like business process outsourcing or call centers which are less skill intensive than the overall industry, but more than a developing economy’s tradition sector of comparative 
advantage. $^{2}$

I will report and analyze the qualitative results of numerical simulations. Begin with fragmentation banned; that is, $\mathrm{M}$ and $\mathrm{S}$ used for $\mathrm{X}$ must be produced in the same location. For this case, I calibrated the model so that the two countries are initially specialized in X (North) and Y (South) in free trade: factor endowments have a bigger spread than factor intensities.

Now allow for the geographic fragmentation of $\mathrm{X}$ production. This results in some or all of the middle-skill-intensive service activity switching from North to South, with services exported back to the North or M export to the South to be combined with S. This doesn't really matter with free trade, except that measured changes in trade volume will depend on which is which. For our purposes, it is perhaps better to think of the services as exported back to North where they are combined with $\mathrm{M}$ to produce the completed good. ${ }^{3}$

There is a fundamental tension that arises in general equilibrium when the ability to fragment manufacturing and services is introduced.

(1) Services, which are middle-skill intensive, shift from North to South, increasing the relative demand for skilled labor in both countries.

This is an idea familiar from Feenstra and Hanson (1996ab, 1997) and also arises in multinationals models (Zhang and Markusen, 1999). North sheds an activity that is unskilledlabor intensive from its point of view, but South gains an activity that is skilled-labor intensive

\footnotetext{
${ }^{2}$ In his discussant's comments, Douglas Irwin quite properly wonders about the robustness of results based on one particular ranking of factor intensities, yet also wants to avoid sliding down the "slippery slope" into taxonomy. I agree with both thoughts. My decision is to concentrate on a central case which I find the most empirically plausible: the offshored service has a middle intensity between $\mathrm{Y}$ and integrated $\mathrm{X}$ production.

${ }^{3}$ Furthermore, allowing the service to be provided by Southern workers is close to the same thing as moving foreign workers to the North. If allowing the service to move results in factor-price equalization, they are exactly the same (provided welfare of each country is that of its original residents).
} 
from its point of view. Thus we expect the real and relative price of skilled labor to rise in both countries.

(2) However, general-equilibrium is bedeviled by terms-of-trade (TOT) effects: the North moves from integrated $\mathrm{X}$ production to exporting $\mathrm{M}$ and importing $\mathrm{S}$. $\mathrm{A}$ fall in the relative price of $\mathrm{M}$ harms North, possibly outweighing efficiency gains for the North.

The ability to fragment $\mathrm{X}$ production has an effect loosely related to a technical improvement. South can produce S more cheaply than in integrated North production and North can produce $\mathrm{M}$ more cheaply. But as the countries begin to specialize, their relative size will do a lot to determine the relative price of $\mathrm{M}$ versus $\mathrm{S}$. The equilibrium relative price of $\mathrm{M}$ to $\mathrm{S}$ is higher, the smaller is the North. When the North is large, an adverse terms-of-trade change can make it worse off than before fragmentation despite the efficiency gain. When the North is not large, efficiency gains outweigh the terms-of-trade shift and both countries benefit. ${ }^{4}$

Closely related to this are two results that emerge from the simulations. First, my results indicated that, while skilled labor is the relative gainer in the North, both factors could suffer a absolute loss of real income when the North is large. This occurs with a low equilibrium relative price for M as just mentioned. Second, results indicate that skilled labor is an absolute gainer in the South, but that it might be a relative looser when the South is large. The South shifts its output to a more skilled-labor-intensive sector, but that sector (services) suffers a price fall relative to the no-fragmentation case. The latter effect is large when the South is large: skilled labor gains absolutely but loses relatively. Results from my simulations over a range of

\footnotetext{
${ }^{4}$ An alternative intuiting about the terms-of-trade effect is as follows. The North has a factor endowment that is well suited to integrated $\mathrm{X}$ production. When fragmentation is allowed, the equilibrium price of $\mathrm{X}$ falls, harming the North which specializes in X. The question is whether or not shifting to specialization in $\mathrm{M}$ more than recoups this loss. The answer is yes if North is not large. Perhaps this intuition also shows why the South always gains: this terms-of-trade effect against X must benefit the South.
} 
parameter values can be summarized as:

$\underline{\text { Results: Model } 1}$

(1) South gains, North loses if North large; both countries gain if South large ${ }^{5}$

(2) Skilled labor is the relative gainer in North

(but real-income loser if South small: tot effect dominates)

(3) Skilled labor is a real-income gainer in South

(but gains relatively less if South large: tot effect dominates)

(4) Unskilled labor is a real-income gainer in South, loser in North

(4) Volume of trade in goods increases: goods and services trade are complements

(but can fall if South small: S is self-sufficient in S, doesn't export)

In spite of doing countless runs of this model, I cannot guarantee that there are not other possibilities and, of course, reordering the factor intensities will change the results. What I can say is that it is easy to find ranges of parameters that generate these results, but we should all regard them as suggestive and not definitive.

5. $\quad$ Model 2: a 3x3x2 missing input model with fragmentation

My second model is designed to capture the idea that skilled labor can be cheap where it is scarce. It again has three production activities, and two countries, but three factors.

${ }^{5}$ A finding that North can lose is not new. Gomory and Baumol (2004) note this in a model with increasing returns, Samuleson (2004) shows a case with constant returns and perfect competition. Many other such cases occur in models with multinationals (Markusen, 2002). Note that some results "guaranteeing" gains from trade compare autarky to free trade with fragmentation (Deardorff, 2005). To me this is irrelevant: the relevant question is comparing free trade in goods to free trade in goods and services. 
(A) Three factors of production: skilled (H) and unskilled (U) labor and know-how (K). K could be high-tech physical capital, such as telecommunications equipment and networks or knowledge capital (managerial techniques, organization infrastructure, marketing channels)

(B) Two final goods, three production activities

$$
\begin{array}{llll}
\text { Y } & - & \text { unskilled-labor intensive } \\
\text { X } & - & \text { skilled-labor and know-how intensive } \\
\text { X } & - & \text { can fragment into high-tech manufacturing (M) and services (S) } \\
& \text { M } & - & \text { more skilled-labor intensive than X } \\
& \text { S } & - & \text { skilled labor and know-how intensive }
\end{array}
$$

(C) Skilled labor and know-how are complements in the production of $\mathrm{S}$

(D) Two competitive, constant returns economies:

North - $\quad$ high-skilled and know-how abundant:

South - low-skilled abundant, very know-how scarce

The complementarity between skilled-labor and know-how in producing $\mathrm{S}$ is crucial. Specifically, this is modeled as a very low elasticity of substitution between $\mathrm{H}$ and $\mathrm{K}$ in producing S. When a country is very know-how scarce, there is little for its skilled workers to do. You can train engineers, but there are no jobs for them.

Assume initially that K (or its services) and skilled workers cannot move between countries. $\mathrm{K}$ is used with skilled workers largely in the North, which exports integrated $\mathrm{X}$. The fundamental tension from introducing trade in $\mathrm{K}$ and $\mathrm{S}$ is now going to occur between Northern and Southern skilled workers.

(1) Skilled-labor is initially cheap in South (even though scarce) due to lack of K to work with. 
(2) Skilled labor in North and South compete directly, introduction of trade in K moves K to South, shifting relative demand for skilled labor to the South.

The introduction of the third factor, complementary with skilled labor, makes it straightforward to create a situation where skilled labor is initially cheap where it is scarce. In addition, the model is less sensitive to country-size issues, at least with respect to factor prices. But as in the case of the previous model, there is terms-of-trade issue for the North. The ability of the owners of $\mathrm{K}$ to move their factor to the South to work with cheap skilled labor there not only erodes the return to skilled labor in the North, but also the North's implicit monopoly power over good $\mathrm{X}$. The result in all of my simulations was that welfare decreases in the North when trade in $\mathrm{K}$ and $\mathrm{S}$ are permitted and the North is large. As in the previous model, the both countries gain when the North is not large. Here are my results for permitting trade in K and S.

\section{Results: Model 2}

(1) South gains, North loses when North large; both gain when North is not large

(2) Skilled labor is real-income loser in North, absolute gainer in South

(3) Real return to know-how rises in North, falls in South

(3) Unskilled labor is real-income gainer in North, loser in South

(4) Volume of trade in goods increases (complements with services)

Losses to the North and northern skilled labor in particular are precisely two of the things that analysts have worried about with respect to the offshoring of white-collar services. This model potentially validates the worry that northern business owners or owners of particular physical capital and knowledge-based assets will benefit considerably at the expense of northern skilled workers. Of course, the model is in part deliberately designed to do that, so this is hardly a coincidence. I cannot say with any confidence that a thorough search would not lead to some 
alternative models with quite different results. On the other hand, I would not have put this model forward if I didn’t find it empirical plausible and relevant.

\section{6. $\quad$ Model 3: a 3x2x2 knowledge capital models of multinationals}

Now I would like to return to something close to model 1, but add in multinational firms following the knowledge-capital model of the multinational that I developed some time ago. This version of the model is based on Zhang and Markusen (1999) (Markusen, 2002, is the best source for the complete development of the theory, and this section is based on Chapter 9).

(A) Two factors of production: skilled (H) and unskilled (U) labor

(B) Two final goods, three production activities

Y - $\quad$ unskilled-labor intensive, constant returns, perfect competition

X $\quad$ - $\quad$ skilled-labor intensive, increasing returns at the firm level: firm and establishment-level fixed costs, constant marginal cost

X $\quad$ - $\quad$ can fragment into high-tech manufacturing (M) and services (S)

M - $\quad$ more skilled-labor intensive than X. By assumption, only North can produce $M$.

S - $\quad$ middle skill intensity: less than $\mathrm{X}$, more than $\mathrm{Y}$

(C) Cournot output competition by X firms, free entry and exit in two firm types

National firms: $\quad$ produce $\mathrm{M}$ and $\mathrm{S}$ in the North, export $\mathrm{X}$ to South

Multinational firms: produce $\mathrm{M}$ in the North which is exported to South where $\mathrm{S}$ is produced, or vice versa

(D) Two economies:

North - high-skilled abundant:

South - low-skilled abundant: 
The reader will see that this resembles model 1 insofar as X can fragment into a skilledlabor-intensive phase and a medium skilled-labor intensive phase. I have modeled the S phase as largely unskilled-labor intensive in marginal costs, but establishment fixed costs as having a sizable skilled-labor component. I do not think that this affects the results.

A nice feature of this model, aside from its probable empirical relevance, is that it avoids the "curse of Stolper-Samuelson”6 and the terms-of-trade effects that are so important in the competitive, constant-returns models. Because of pro-competitive effects leading to increased firm scale and lower markups, it is entirely possible that both countries and all factors gain following a liberalization. ${ }^{7}$

The way this works in the present model is straightforward. Again, begin in a situation where trade in disembodied S is not allowed: $\mathrm{S}$ and $\mathrm{M}$ must be produced together. This is equivalent here to not allowing multinationals to enter. Having to use North's factor endowment for both $\mathrm{M}$ and $\mathrm{S}$ is a binding constraint on the world economy, and limits the number of firms in free-entry equilibrium which in turn leads to a high markup and a low output per firm (high average cost). When this constraint is relaxed by allowing firm to fragment $\mathrm{X}$, much, perhaps all of service production moves to South. This again tends to have the Feenstra-Hanson effect of raising the relative demand for skilled labor in both countries. But now this also increases the profitability of the existing firms which leads to entry which in turn leads to lower markups and higher output per firm (lower average costs).

${ }^{6}$ I didn’t invest this phrase, I wish I had. I think I heard it first from Ron Jones.

${ }^{7}$ Alternatively, we could model the final goods or intermediate services as differentiated, using the now well-known large-group monopolistic-competition framework. As far as welfare is concerned, there is a benefit from increased variety analogous to the pro-competitive effect of the oligopoly model that tends to generate large welfare gains. See Ethier (1982) and extensions by Markusen (1989). 
There are however, a lot of possibilities depending on relative endowments and intensities and again on country size. Chapters 8-9 of Markusen (2002) shows that many outcomes are possible. I can say that it is easy to find parameter values for which allowing fragmentation leads to welfare increases for both countries and gains for skilled labor in both countries. I have to admit that I did not find a set of parameters for which the real prices of all four factors increase, however. I generally tended to find that the real return to unskilled labor in the North fell following fragmentation and trade in services. Here are some typical, but not robust, set of results for the effects of allowing multinationals to enter, equivalent here to allowing trade in services.

$\underline{\text { Results: Model } 3}$ (for a range of parameterizations)

(1) South gains, North gains

(2) Skilled labor is relative and absolute gainer in North and South

(3) Unskilled labor loses in the North and gains in the South

(4) Pro-competitive effects lead to more firms, lower markups, higher output per firm

7. Model 4: a 3x3x2 that combines the knowledge-capital model with the missing factor $\underline{\text { model }}$

Our fourth template combines the knowledge-capital model with the missing factor model. I take the skilled labor in the North, and assume that some portion of it is factor K, which is a complementary with skilled labor in producing establishment fixed costs. In fact, I coded up this model first and then moved to model 3 by simply allowing the substitution between $\mathrm{K}$ and $\mathrm{H}$ in producing establishment fixed costs to move to infinity. Otherwise, the models are the 
same.

In the initial equilibrium, trade in $\mathrm{K}$ (or the services of $\mathrm{K}$ ) is not permitted; alternatively, multinational firms are not permitted to enter. These results are then compared to allowing trade in $\mathrm{K}$, or equivalently allowing multinationals to enter. Again, a range of outcomes are possible. But for the same parameterization as Model 3 just indicated, the liberalization here generates a stronger adverse terms-of-trade effects for North. North's welfare declines if the North is large. As in the case of Model 2, it is now the case the skilled labor in North competes directly with skilled labor in South. The introduction of multinationals moves K from North to work with initially cheaper skilled labor in South. This lowers the real return to skilled labor in North with the big beneficiary being owners of the factor K.

\section{$\underline{\text { Results, Model } 4}$}

(1) South gains, North loses if North big; both gain if South big

(2) Skilled labor is relative and real-income loser in North, gainer in South

(3) Large gain in North for the owners of know-how.

(4) Unskilled labor gains in both countries

(5) Pro-competitive effects lead to more firms, lower markups, higher output per firm.

\section{The offshoring-outsourcing (internalization, mode choice) relationship}

Internalization or its inverse, outsourcing, is a decision about the boundaries of the firm and what activities to keep inside or internal to the firm's ownership structure and which to contract to arm’s length firms. Multinationals offshore but do not outsource, keeping their foreign activities within owned foreign affiliates. Firm that contract or license in some way to 
foreign firms are engaging in both offshoring and outsourcing.

As I indicated earlier, the internalization decision, also known as mode choice, has had a long history of analysis, particularly in the international business literature. Its rediscovery under the name outsourcing has coincided with many researchers overlooking this long tradition. In any case, the traditional focus of the internalization/outsourcing decision has been on the various transactions costs, particularly when offshoring, of doing business arm's length rather than internal to the firm.

It is important to keep offshoring and outsourcing decisions distinct: they are location choice and mode choice decisions respectively. Some factor that might encourage outsourcing might at the same time discourage offshoring in favor of exporting from the home country or choosing a third country.

There are in fact a number of problems for producing abroad that do precisely this: they encourage outsourcing but discourage offshoring. Some of these are:

(1) restrictions on foreign investment

(2) restrictions on the right of establishment

(3) restrictions on immigration (generally temporary) of foreign business personnel

(4) lack of intellectual property protection

(5) lack of contract enforcement

The first three in this list generally follow from the fact that offshoring requires setting up a foreign subsidiary which in turn requires foreign investment and the use of home-country personnel in the host country for some period of time. Thus problems in any of these three areas would encourage a firm to outsource to a local firm, but they also discourage offshoring relative 
to other outside alternatives.

Points (4) and (5) involve various aspects of moral hazzard and hold up when firms make investments, both sunk physical capital and investments in training local workers, in connection with establishing a subsidiary. Again, they tend to encourage outsourcing but also discourage offshoring. The problem of transferring knowledge and skills probably exists for both modes of offshoring, about which I will say more shortly.

Two formal approaches found in the theory literature may be useful. The first I will term the "labor-learning model”. Variations of this are found in Ethier and Markusen (1996), Fosfuri, Motta and Rønde (2001), Markusen (2001), and Glass and Saggi (2002). In all of these papers, multinationals make a foreign investment which is profitable due to knowledge-based assets of the firm. However, workers in the host country learn this knowledge themselves, and can later defect to start a rival firm. If binding contracts cannot be written, then the firm will have to pay these workers a premium in subsequent periods to hold them in the firm. Thus the multinational must share rents with local employees if contracts cannot be written or enforced.

A second promising line of research involves the Grossman and Hart (1986) hold-up model, which has been developed in a series of papers by Antrás (Antrás 2003, 2005, Antrás and Helpman 2004). Here the idea is that the multinational firm and a local agent must each make sunk, relationship-specific investments in a project. In the absence of complete contracts or contract enforcement, this creates a bi-lateral ex-post-hold-up problem. The optimal mode of entry is generally that ownership, defined as residual rights in assets if bargaining breaks down, should go to the party with the larger sunk investment. As in the labor-learning model, this approach requires the multinational to share rents with a local agent whether or not that agent is 
the manager of an owned subsidiary or the owner of an arm's-length contractor.

Alternative assumptions can produce alternative correlations between offshoring and outsourcing. Suppose that a firm wishes to supply a product X in South. If fixed costs of setting up a foreign plant are not too large but large relative to sunk investments of the local partner, then the firm will tend to choose both offshoring (in preference to exporting) and internalization: a negative correlation between offshoring and outsourcing.

A difference between the labor-learning model and the hold-up model is that, in the latter, the both the multinational and the local manager make ex-ante sunk investments that generate bilateral hold up. In the labor-learning model, workers acquire bargaining power ex post as they learn. Thinking about the offshoring of white-collar services, I think that both approaches have something to contribute. There is no question that there are a lot of training costs for the foreign workers. For IT and BPO activities, they are often learned on the job by workers already possessing good general skills. It is my understanding that many call-center workers are training by independent firms prior to landing a call-center job.

Here is my suggestion for one approach which combines the labor-learning approach and the sunk-cost hold-up approach. Think of this as, perhaps, a model of business process outsourcing or call centers.

Model 5: $\quad$ Template for an integrated outsourcing/offshoring approach

(A) Begin with the "missing input model", two time periods

(B) Interpret this as firm-specific knowledge-capital ala Markusen’s knowledgecapital model: skilled workers in the host country are cheap because they lack crucial physical or knowledge-based inputs.

(C) With appropriate technological and institutional conditions, this asset can be “exported” by a firm (used abroad) in combination with local skilled workers. 
(D) However, local workers "absorb” the relevant knowledge and are able to "defect” to start rival firms on their own in the second period.

(E) Also assume a capital investment in land, structures, and telecommunications is needed. Whoever owns this defines whether the project is a subsidiary (internalization) or an arm's length relationship (outsourcing). The cost must be borne by the multinational.

I suppose that many researchers in the international business field would conjecture that given complete and enforceable contracting, the firm would prefer outsourcing on a simple cost basis, so let's make that as an assumption.

$\underline{\text { Results: Model } 5}$ (conjectures! this paper has not been written!)

(1) Given complete and enforceable contracts, outsourcing is preferred (by assumption).

(2) If contracts are not enforced, then the multinational will want to own the physical capital, i.e., internalization is chosen by the Grossman-Hart-Antrás argument.

(3) However, even if physical capital is contractible (local firm contracts to pay a mortgage), the firm may still want to own it if intellectual capital (skills) transferred to local workers are not, in order to reduce the ex-post hold up problem of skilled workers threatening to leave.

(4) On the other hand, if the learned skills of the foreign manager is relationship-specific; i.e., they are only useful to the contracting multinational, then there is limited hold up from the workers and outsourcing would be preferred. Indeed, in this case it seems as though the firm has ex post hold up power, and so the manager would want to own the capital.

Again, these are conjectures. I am currently working on this project, but not yet certain of the results. As a final point, recall again that the agency costs and rent sharing costs to the firm, whether they be less in the internal or outsourcing mode, also affect the firms offshoring choice. For firms seeking to serve the local host market, these costs may lead the firm to choose exports rather than offshoring. For firms seeking to serve their own home market, these costs may lead it to choose domestic outsourcing or search for a third supplier. 


\section{9. $\quad$ Summary and conclusions}

I have argued in this paper that we can make good progress in understanding the offshoring of white-collar services at the theory level from our existing portfolio of models. Many important features of offshoring of white-collar services can be modeled from a recipe that mixes and matches elements from the existing inventory. Useful elements from our portfolio include:

(A) vertical fragmentation of production

(B) expansion of trade at the extensive margin

(C) fragments differ in factor intensities, countries differ in endowments

(D) knowledge stocks of countries or firms that are complementary to skilled labor create missing inputs for countries otherwise be well suited to skill-intensive fragments

(E) these knowledge-based assets however create particular contractual and agency issues for firms engaging in international business. Existing models of labor-learning and holdup are useful places to start in considering the outsourcing (mode) choice in relation to the offshoring (location) choice.

These features allow us to construct relatively simple and tractable general-equilibrium models which predict changes induced by fragmentation on aggregate welfare, factor prices (income distribution), the location of production activities, and the direction and volume of trade.

While I view the paper as listing a number of plausible and empirically-relevant ways of modeling the offshoring of white-collar services, it was clear at the conference that many people were much more interested in specific results from these models. Unfortunately, it is hard to offer robust conclusions, especially about the aggregate welfare of countries. Trade theorists are 
well aware of the underlying problem: any move from partial liberalization to more liberalization (allowing more things to be traded in our case) often does not result in Pareto improvements for the trading partners. It would be intellectually dishonest for me to report only cases in which everyone is better off.

Overall, my simulation models suggest a clear gain for world welfare and for the South in particular, but the North may lose if it is large. This result is actually very familiar to all trade theorists in different contexts; e.g., a large country may well prefer a Nash equilibrium in tariff rates to free trade with a small country. Stephen Magee (2005), in a recent very provocative paper, has argued persuasively that the US is not a large country in the sense of my models, which might give us some comfort.

Results on factor-price changes are interesting and consistent with a range of existing literature. In the two-factor models, skilled labor is the relative and (generally) absolute gainer in both regions, as activities that are not skill intensive from the North's point of view are transferred to the South where they are. Results for unskilled labor are more mixed.

I have been asked to indicate which model may fit reality the best, and I have to say that I think that the three-factor "missing input” model is my favorite, preferably with multinationals. I have called this third factor "knowhow”: it could be knowledge capital, high-tech physical capital, or highly skilled knowledge workers, including management. I actually started working with this model in connection with Central and Eastern Europe, where it was clear that workers with excellent skills in math, science and engineering had very low productivity: they were missing crucial organizational, managerial, quality control, and marketing skills needed to go with their general skills. Many case studies I have read about East Asia suggest exactly the same 
thing. You can educate scientists or engineers but there is nothing for them to do.

I capture this by making the North rich in knowhow as distinct from general skilled labor, and by making knowhow a strong complement to general skilled labor. The result is that skilled labor is cheap in the South where it is scarce, a principal stylized fact that has generated much of the white-collar offshoring. This model sets up a tension between the general northen skilled labor and the southern skilled labor, perhaps routine programmers and routine business-process workers are examples. Allowing fragmentation moves knowhow or rather the services of the knowhow to the South, generating big gains from the owners of the knowhow and losses for general skilled labor in the North. We should keep in mind, however, that much of the knowhow is surely embodied in the human capital of highly skilled tech-workers, managers, marketeers and so forth, and so this result may suggest that second-level white-collar workers are the ones who are most at risk.

I will close again with another caveat about theory. While it is frustrating for readers and policy makers, strong and robust findings about welfare gains from fragmentation are not forthcoming from a general approach to theory or, alternatively, it is usually possible to find some strange model that generates whatever result the client wants. I have tried to construct models that I feel are plausible and relevant, but even then there is some residual ambiguity. I hope I have at least left us with some sense of why this ambiguity exists. 


\section{REFERENCES}

Antràs, Pol. 2003. "Firms, Contracts, and Trade Structure”. Quarterly Journal of Economics 118: $1374-1418$.

Antràs, Pol. 2005. "Incomplete Contracts and the Product Cycle”. American Economic Review, forthcoming.

Antràs, Pol and Elhanan Helpman. 2004. "Global Sourcing”. Journal of Political Economy 112: $552-580$.

Bhagwati, Jagdish, Arvind Panagariya and T.N. Srinivasan.2004. “The Muddles over Outsourcing”. Journal of Economic Perspectives 18: 93-114.

Brainard, S. Lael. 1997. "An Empirical Assessment of the Proximity-Concentration Tradeoff between Multinational Sales and Trade". American Economic Review 87: 520-544.

Deardorff, AlanV. 2001. “Fragmentation in Simple Trade Models”. North American Journal of Economics and Finance 12: 121-137.

Deardorff, Alan V. 2004. “A Trade Theorist’s take on Skilled-Labor Outsourcing”. Research seminar in International Economics, Discussion Paper No. 513, University of Michigan.

Deardorff, Alan V. 2005. “Ricardian Comparative Advantage with Intermediate Inputs”. North American Journal of Economics and Finance 16: 11-34.

Dornbusch, Rudiger, Stanley Fischer and Paul A. Samuelson.1977. “Comparative Advantage, Trade, and Payments in a Ricardian Model with a Continuum of Goods”. American Economic Review 67: 823-839.

Dunning, John H.1977. "Trade, Location of Economic Activity and : A Search for an Eclectic Approach", In Ohlin, B., P. O. Hesselborn, and P.M. Wijkman (eds.). The International 
Allocation of Economic Activity. Macmillan.

Ethier, Wifred. 1982. "National and International Returns to Scale in the Modern Theory of International Trade”. American Economic Review 72: 389-405.

Ethier, Wilfred. 1986. "The Multinational Firm". Quarterly Journal of Economics 101: 805-833.

Ethier, Wilfred and James R. Markusen.1996. "Multinational Firms, Technology Diffusion and Trade". Journal of International Economics 41: 1-28.

Feenstra, Robert C. and Gordon H. Hanson.1996a. "Foreign Investment, Outsourcing, and Relative Wages". in R.C. Feenstra, G.M. Grossman, and D.A. Irwin (editors), The Political Economy of Trade Policy: Papers in Honor of Jagdish Bhagwati, MIT Press.

Feenstra, Robert C. and Gordon H. Hanson. 1996b, "Globalization, Outsourcing, and Wage Inequality". American Economic Review 86: 240-245.

Feenstra, Robert C. and Gordon H. Hanson.1997. "Foreign Direct Investment and Relative Wages: Evidence from Mexico's Maquiladoras". Journal of International Economics 42: 371-393.

Fosfuri, Andrea, Massimo Motta and Thomas Rønde.2001. “Foreign Direct Investment and Spillovers through Worker Mobility”. Journal of International Economics 42: 205-221.

Glass, Amy Joyce and Kamal Saggi. 2002, “Multinational Firms and Technology Transfer”. Scandinavian Journal of Economics 104: 495-513.

Gomory, Ralph E. And William J. Baumol.2004. “Globalziation: Prospects, Promise, and Problems”. Journal of Policy Modeling 26: 425-438.

Grossman, Stanford J. And Oliver D. Hart.1986. “The costs and Benefits of Ownership: A Theory of Vertical and Lateral Integration”. Journal of Political Economy 94: 691-719. 
Grubel, Herbert. 1987. “All Traded Services are Embodied in Materials or People”. The World Economy 10.

Helpman, Elhanan.1984. "A Simple Theory of Trade with Multinational Corporations". Journal of Political Economy 92: 451-471.

Helpman, Elhanan, Mark J. Melitz, and Stephen R. Yeaple.2004. “Exports versus FDI with Heterogeneous Firms”. American Economic Review 94: 300-316.

Horstmann, Ignatius J. and James R. Markusen.1987. "Licensing Versus Direct Investment: A Model of Internalization by the Multinational Enterprise". Canadian Journal of Economics 20: 464-481.

Hummels, David, Jun Ishii and Kie-Mu Yi. 2001. “The Nature and Growth of Vertical Specialization in World Trade”. Journal of International Economics 54: 75-96.

Jones, Ronald W., I. Coelho, and Stephen T. Easton.1986. "The Theory of International Factor Flows: the Basic Model". Journal of International Economics, 1986: 313-327.

Koopmans, Tjalling.1957. Three Essays on the State of Economic Science, McGraw Hill.

Markusen, James R.1983. “Factor Movements and Commodity Trade as Complements”. Journal of International Economics 14: 341-356.

Markusen, James R.1984. “Multinationals, Multi-Plant Economies, and the Gains from Trade”. Journal of International Economics 16: 205-226.

Markusen, James R.1989. "Trade in Producer Services and in Other Specialized Intermediate Inputs". American Economic Review 79: 85-95.

Markusen, James R.1995. "The Boundaries of Multinational Firms and the Theory of International Trade". Journal of Economic Perspectives 9: 169-189. 
Markusen, James R. 2001. “Contracts, Intellectual Property Rights, and Multinational Investment in Developing Countries”. Journal of International Economics 53: 189-204.

Markusen, James R 2002. Multinational Firms and the Theory of International Trade, Cambridge: MIT Press.

Markusen, James R., and Anthony J. Venables. 2005. “A Multi-country Approach to Factors Proportions Trade and Trade Costs”. NBER working paper 11051.

McGee, Stephen P. and Kwang-Yeol Yoo. 2005. "The United States is a Small Country in World Trade: Further Evidence and Implications for Globalization”. University of Texas working paper.

Melitz, Mark J. 2003. “The Impact of Trade on Intra-Industry Reallocations and Aggreate Industry Productivity”. Econometrica 71: 1695-1725.

Mundell, Robert A. 1957. "International Trade and Factor Mobility. "American Economic Review 47: 321-335.

Neary, J. Peter 1995. "Factor Mobility and International Trade". Canadian Journal of Economics 28: 1995, S4-S23.

Norman, V.D and A.J. Venables. 1995. “International trade, factor mobility and trade costs”. Economic Journal 105: 1488-1505.

Samuelson, Paul A. 2004. "Where Ricardo and Mill Rebut and Confirm Arguments of Mainstream Economists Supporting Globalization”. Journal of Economic Perspectives 18: $135-146$.

Yi, Kei-Mu. 2003. “Can Vertical Specialization Explain the Growth of World Trade”. Journal of Political Economy 111: 52-102. 
Zhang, Kevin Honglin and James R. Markusen. 1999. "Vertical Multinational and Host Country Charateristics”. Journal of Development Economics 59: 233-252. 
APPENDIX: Example of the simulation models used in the paper

The models in the paper seem simple enough. The first model begins with the classic 2x2x2 workhorse model of trade theory. All students of economics learn the analytics of this model, many of these as undergraduates. Any economist can reasonably conjecture that introducing the ability to geographically fragment some activities should still permit analytical solutions.

Unfortunately, it is not nearly that simple. Let us take Case 1 as an example, our simplest model. We go from two to four production activities: Y, M, S, and final X instead of just Y and $\mathrm{X}$. The number of possible production specialization patterns for a country goes from 3 to 15 (assumes that you have to produce some of something). In addition, there are a great many more possible trade patterns, the number going from 2 to 14. In other words, the dimensionality of the model increases greatly, making the simple analytical methods we are use to much less useful.

Second, the entire model must now be formulated in terms of inequalities, not equations. We do not know which of these will hold for a particular set of parameters (e.g., which production activities and which trade activities are slack), and indeed the set that holds with equality will typically change a lot when parameters are changed. Allowing fragmentation can, for example, reverse the direction of trade in $\mathrm{X}$ and/or $\mathrm{Y}$. The models are termed non-linear complementarity problems in math programming language: each weak inequality is associated with a non-negative complementary variable. If an inequality holds as a strict equality in the solution, the complementary variable is positive; if it holds as a strict inequality (e.g., marginal cost exceed price), the complementary variable (quantity in this case), is zero. . Traditional comparative-statics techniques used on sets of equalities are of no use. If you read some of the 
existing literature on production fragmentation, you will then understand why almost none of it actually solves for a world general equilibrium.

Thus I have chosen to approach the template models using simulations. I use software from GAMS, which has the only powerful and robust non-linear complementarity solver in the business. All models consist of three sets of inequalities and complementary variables. First, there are zero-profit inequalities for each production and trade activity: marginal cost is greater than or equal to price. The complementary variable is the output or "activity level" of that activity. A quantity variable is complementary with the price inequality.

Second, there are market clearing inequalities: supply of a commodity (good, factor, import, etc.) is greater than or equal to its demand. The complementary variable is the price of that commodity. A price variable is complementary to a quantity equations. Finally there is an income balance equation for each country.

In this appendix, I give the set of inequalities for model 1. There are 34 production and trade activities, 24 “commodities” (final goods, intermediate goods, imports and exports, and utility, which is treated as a good produced from inputs of $\mathrm{X}$ and $\mathrm{Y}$ in the code), and two income levels. Walras' Law makes one equation redundant: I fix the world price of Y at 1 , and drop the world market-clearing equation for Y. Thus the entire model consists of 59 weak inequalities each with an associated non-negative variable.

In the body of the paper, I introduced only the notation needed to describe the models in basic economic terms. Here are the definitions of additional notation need for the formal model. $p_{k i} \quad$ producer price (i.e., marginal cost) of good $\mathrm{k}$ in country $\mathrm{i}$

$$
(\mathrm{k}=\mathrm{Y}, \mathrm{X}, \mathrm{M}, \mathrm{S} ; \mathrm{i}=\text { North, South) }
$$




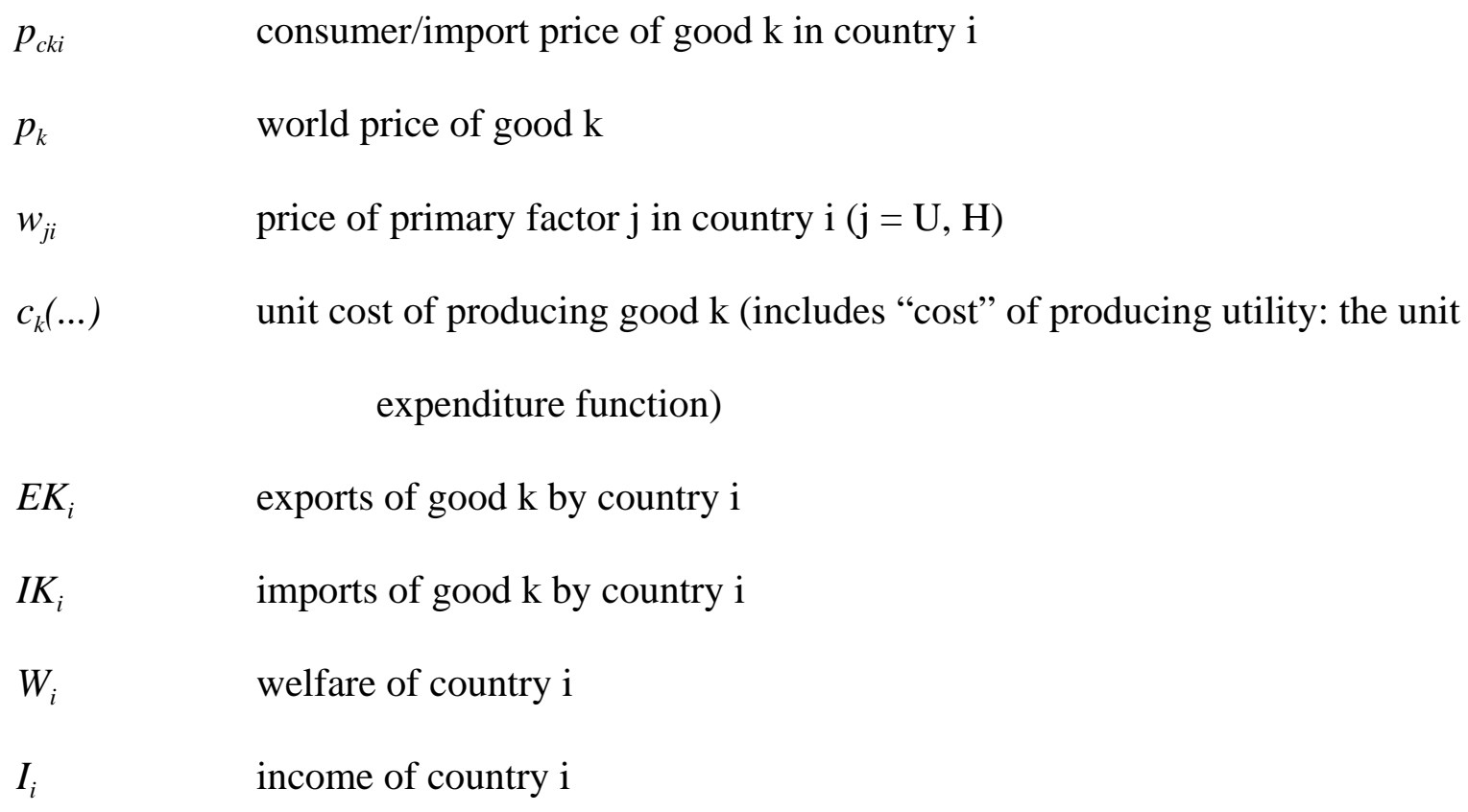

Other:

(1) market-clearing inequalities make extensive use of Shepard's lemma, in which the unit demand for a good or factor is the derivative of the unit cost function with respect to the price of that good or factor.

(2) very small trade costs, $0.05 \%$, are used to prevent “ties" or, more formally, model degeneracy. This prevents, for example, it being equally profitable to both import and export a good, which would lead to indeterminancy of gross trade flows and possibly a failure to solve (infinitely many solutions differing in gross trade flows).

(3) solutions without fragmentation permitted are computed by constraining import and export activities for $\mathrm{S}$ and $\mathrm{M}$ to be zero.

(4) all production activities using more than one input are Cobb-Douglas, with shares as follows: 


$\begin{array}{llll}\mathrm{Y} & - & \mathrm{U}: 0.70 & \mathrm{H}: 0.30 \\ \mathrm{M} & - & \mathrm{U}: 0.17 & \mathrm{H}: 0.83 \\ \mathrm{~S} & - & \mathrm{U}: 0.60 & \mathrm{H}: 0.40 \\ \mathrm{X} & - & \mathrm{M}: 0.70 & \text { S: } 0.30\end{array}$

implied shares of primary factors in X produced from domestic $\mathrm{M}$ and $\mathrm{S}$ are the inverse of share for Y.

$$
\mathrm{X} \quad-\quad \mathrm{U}: 0.30 \quad \mathrm{H}: 0.70
$$

(5) factor endowments ratios for North and South are symmetric:

$$
\begin{array}{lll}
\text { North }- & \text { H: } 0.90 & \text { U: } 0.10 \\
\text { South - } & \text { H: } 0.10 & \text { U: } 0.90
\end{array}
$$

The model is thus symmetric between North and South and between $\mathrm{X}$ and $\mathrm{Y}$ without fragmentation. Endowment ratios having a bigger spread (9/1) than intensities (7/3). If countries are the same size, then the no-fragmentation equilibrium is symmetric with both countries specialized, a goods terms of trade of one, factor-price ratios that are inverses in the two countries, and equal welfare across countries. 
$\underline{\text { Inequalities }}$

$\underline{\text { zero profit inequalities }}$

$c_{y}\left(w_{u i}, w_{h i}\right) \geq p_{y i}$

$c_{m}\left(w_{u i}, w_{h i}\right) \geq p_{m i}$

$c_{s}\left(w_{u i}, w_{h i}\right) \geq p_{s i}$

$c_{x}\left(p_{m i}, p_{s i}\right) \geq p_{x i}$

$c_{x}\left(p_{m i}, p_{c s i}\right) \geq p_{x i}$

$c_{x}\left(p_{c m i}, p_{s i}\right) \geq p_{x i}$

$c_{x}\left(p_{c m i}, p_{c s i}\right) \geq p_{x i}$

$p_{m i} \geq p_{m}$

$p_{m} \geq p_{c m i}$

$p_{s i} \geq p_{s}$

$p_{s} \geq p_{c s i}$

$p_{x i} \geq p_{x}$

$p_{x} \geq p_{x i}$

$p_{y i} \geq p_{y}$

$p_{y} \geq p_{c y i}$

$p_{c y i} \geq p_{y i}$

$c_{w}\left(p_{x i}, p_{c y i}\right) \geq p_{w i}$ $\underline{\text { Complementary variable }}$

activity levels $\quad$ description (no. of inequalities)

$Y_{i}$

production of $\mathrm{Y}$ in i (2)

$M_{i} \quad$ production of $\mathrm{M}$ in i (2)

$S_{i}$

production of S in i (2)

$X_{d i}$

production of $X_{i}$ from $S_{i}, M_{i}(2)$

$X_{s i}$

production of $X_{i}$ from $S_{j}, M_{i}(2)$

$X_{m i}$

production of $X_{i}$ from $S_{i}, M_{j}(2)$

$X_{n i}$

production of $X_{i}$ from $S_{j}, M_{j}(2)$

$E M_{i} \quad$ exports of M by i (2)

$I M_{i} \quad$ imports of $\mathrm{M}$ by i (2)

$E S_{i} \quad$ exports of S by i (2)

$I S_{i} \quad$ imports of S by i (2)

$E X_{i} \quad$ exports of $\mathrm{X}$ by i (2)

$I X_{i} \quad$ imports of $\mathrm{X}$ by i (2)

$E Y_{i} \quad$ exports of $\mathrm{Y}$ by i (2)

$I Y_{i} \quad$ imports of $\mathrm{Y}$ by i (2)

$Y Y_{i} \quad$ home supply of $\mathrm{Y}_{\mathrm{i}}$ to i (2)

$W_{i} \quad$ production of welfare in i (2) 
$\underline{\text { market clearing inequalities }}$

$Y_{i} \geq Y Y_{i}+E Y_{i}$

$Y Y_{i}+I Y_{i} \geq \frac{\partial c_{w i}}{\partial p_{c y i}} W_{i}$

$M_{i} \geq \frac{\partial c_{x}}{\partial p_{m i}} X_{d i}+\frac{\partial c_{x}}{\partial p_{m i}} X_{s i}+E X_{i}$

$I M_{i} \geq \frac{\partial c_{x}}{\partial p_{c m i}} X_{m i}+\frac{\partial c_{x}}{\partial p_{c m i}} X_{n i}$

$S_{i} \geq \frac{\partial c_{x}}{\partial p_{s i}} X_{d i}+\frac{\partial c_{x}}{\partial p_{s i}} X_{m i}+E S_{i}$

$I S_{i} \geq \frac{\partial c_{x}}{\partial p_{c s i}} X_{s i}+\frac{\partial c_{x}}{\partial p_{c s i}} X_{n i}$

$X_{d i}+X_{m i}+X_{s i}+X_{n i}+I X_{i} \geq \frac{\partial c_{w i}}{\partial p_{x i}} W_{i}+E X_{i}$

$\sum_{i} E Y_{i} \geq \sum_{i} I Y_{i}$

$\sum_{i} E M_{i} \geq \sum_{i} I M_{i}$

$\sum_{i} E S_{i} \geq \sum_{i} I S_{i}$

$\sum_{i} E X_{i} \geq \sum_{i} I X_{i}$

$W_{i} \geq I_{i} / p_{w i}$ prices

$p_{y i}$

$p_{c y i}$

$p_{m i}$

$p_{c m i}$

$p_{s i}$

$p_{c s i}$

$p_{x i}$

supply - demand for $\mathrm{X}_{\mathrm{i}}(2)$

world market and price for Y (1)

world market and price for M (1)

world market and price for S (1)

world market and price for X (1)

supply - demand for utility (2) 


$$
\begin{array}{lll}
U_{i} \geq \frac{\partial c_{y i}}{\partial w_{u i}} Y_{i}+\frac{\partial c_{m i}}{\partial w_{u i}} M_{i}+\frac{\partial c_{s i}}{\partial w_{u i}} S_{i} & w_{u i} & \text { market for unskilled labor in i (2) } \\
H_{i} \geq \frac{\partial c_{y i}}{\partial w_{h i}} Y_{i}+\frac{\partial c_{m i}}{\partial w_{h i}} M_{i}+\frac{\partial c_{s i}}{\partial w_{h i}} S_{i} & w_{h i} & \text { market for skilled labor in i (2) }
\end{array}
$$

$\underline{\text { Income balance inequalities }}$

$$
I_{i}=w_{u i} U_{i}+w_{h i} H_{i}
$$

incomes

$I_{i j}$ description (no. of inequalities)

income balance in country i (2) 